\title{
Air dan Peradaban Manusia Pada Zaman Bali Kuno
}

\author{
I Wayan Srijaya, Kadek Dedy Prawirajaya R. \\ Fakultas Ilmu Budaya Universitas Udayana \\ srijaya59@yahoo.com,dedyprawirajaya@unud.ac.id
}

\begin{abstract}
Abstrak
Air adalah salah satu unsur alam yang sangat diperlukan oleh mahluk hidup. Setiap mahluk hidup tidak terkecuali manusia, tidak dapat beratahan tanpa adanya air. Oleh karena itu air menjadi salah satu kebutuhan dasar manusia disamping kebutuhan akan san dan papan. Air berfungsi sebagai pelepas dahaga dikala manusia kehausan, dan berfungsi sebagai penyubur tanaman dikala musim kemarau. Itulah sebabnya air sangat diperlukan dalam menjaga kelangsungan hidup manusia dan mahluk lainnya. Air juga menjadi tempat awal munculnya sebuah peradaban manusia.
\end{abstract}

Kata kunci: air, sawah, peradaban

\begin{abstract}
Water is one of the natural elements that is needed by living things. Every living thing, including humans, cannot stay without water. Therefore water is one of the basic human needs besides the need for sanitation and shelter. Water functions as a thirst quencher when humans are thirsty, and functions as fertilizer for plants during the dry season. That is why water is indispensable for maintaining the survival of humans and other creatures. Water is also the starting place for the emergence of a human civilization.
\end{abstract}

Key words: water, rice fields, civilization

\section{Pendahuluan}

Sejak kehadiran mahluk hidup di bumi, air mempunyai peranan yang sangat penting. Mahluk hidup manusia, hewan, dan tumbuhan tidak akan dapat hidup tanpa air. Manusia sebagai mahluk hidup yang paling tinggi derajatnya diantara ciptaan Tuhan lainnya, 2/3 dari tubuhnya terdiri atas air. Itulah sebabnya manusia tidak akan mampu bertahan apabila kekurangan air. Fungsi utama air untuk menjaga kelangsungan mahluk hidup adalah sebagai pengisi cairan di dalam tubuh. Sebagai pengisi cairan dalam tubuh manusia, maka mahluk hidup manusia haruslah minum air secukupnya. Mahluk hidup khusunya manusia tidak akan mampu bertahan dalam beberapa hari tanpa minum air (Muliarta, 2015: 2). Demikian juga halnya dengan hewan dan tumbuh-tumbuhan. Walaupun hewan dan tumbuh-tumbuhan memiliki daya tahap yang lebih kuat dibandingkan dengan manusia, tetapi tetap membutuhkan air untuk menjaga keseimbangannya. Selain untuk memenuhi kebutuhan akan air baku untuk diminum, air juga digunakan untuk berbagai kepentingan dalam kehidupan manusia. Bagi manusia, air diperlukan untuk memenuhi kebutuhan cairan dalam tubuh. Dapat dibayangkan, seandainya tubuh manusia kekurangan cairan akan mengalami dehidrasi, lemas, pingsan bahkan dapat menyebabkan kematian. Bagi manusia, air juga dapat menyegarkan badan. Ketika tubuh kita kekurangan cairan, maka yang akan kita rasakan adalah badan menjadi lemas dan letih sehingga kehadiran air dalam tubuh akan membuat tubuh kita bugar kembali. Air juga dimanfaatkan untuk meringankan pekerjaan di dalam rumah tangga. Hal ini dapat dipahami, bagaimana mungkin kehidupan manusia dapat berlangsung bilamana tidak tersedia air. Misalnya untuk keperluan mandi, mencuci, menyiram tanaman, dan sebagainya. Demikian pula bagi para petani dan peternak, air sangat diperlukan untuk keberlangsungan bercocok tanam mereka. Demikian pentingnya manfaat air bagi kehidupan mahluk hidup, maka keberadaan sumber-sumber air haruslah tetap dipertahankan.

Dalam perjalan peradaban umat manusia tidak dapat dikesampingkan dari persoalan air. Bahkan beberapa pusat peradaban tertua di dunia muncul dan berkembang pada lembah sungai. 
Peradaban Mahenjodaro dan Harappa menurut hasil penelitian dikatakan sebagai peradaban kota sejak 3500 SM misalnya dibangun di sepanjang aliran Sugai Indus (Noejani, 1992: 90), begitu pula dengan peradaban Mesopotamia di Timur Tengah dibangun ditepi Sungai Eufrat dan Tigris pada tahun 3000 SM yang daerahnya berbatasan dengan laut tengah. Daerah ini merupakan wilayah yang subur sehingga didiami oleh banyak bangsa, yaitu Ubaid, Sumeria, Babilonia, Assyria, dan Persia (Noejani, 1992: 106). Begitu pula dengan peradaban Mesir kuno yang dibangun di sepanjang aliran Sungai Nil sekitar 3100 SM (Noeljani, 1992: 119; Suamba, 2017: 10). Demikian pula dengan peradaban Cina kuno dibangun di lembah Sungai Kuning sekitar 2500 SM (Noeljani, 1992: 125).

Lalu bagaimana dengan peradaban tertua di Indonesia. Dari bukti-bukti arkeologis yang sudah ditemukan menunjukkan hal yang serupa bahkan sejak awal terjadinya hunian di Indonesia sudah memperlihatkan adaptasinya dengan lingkungan sungai. Seperti halnya penemuanpenemuan fosil tertua oleh Dubois maupun Koenigswald, tidak jauh dari lembah sungai Trinil di Sangiran (Soejono, ed; 2000: 159). Ini membuktikan bagaimana manusia senantiasa bergantung dengan air sebagai salah satu komponen untuk memenuhi kebutuhan jasmaninya. Mereka bertempat tinggal atau mencari tempat berlindung berupa goa-goa alam yang dekat dengan air seperti sungai maupun laut. Pada tempat-tempat seperti inilah manusia dapat memenuhi kebutuhan hidupnya dengan memanfaatkan potensi biota laut maupun ikan yang ada disungai dengan cara menangkapnya baik dengan menggunakan pancing ataupun jaring (Soejono ed, 2000: 176).

\section{Tujuan dan Manfaat Penelitian}

Penelitian ini bertujuan untuk mengetahui bagaimana peranaan dan kedudukan air dalam kaitannya dengan peradaban manusia pada zaman Bali Kuno. Sekalipun tidak ada bukti kuat yang memperlihatkan bahwa peradaban Bali Kuno muncul pada lembah-lembah sungai seperti di uraikan di atas, namun kenyataan empiris menunjukkan bahwa betapa pentingnya air dalam menentukan peradaban manusia. Salah satu contoh yang dapat dikemukakan adalah munculnya pusat-pusat keagamaan yang berupa bangunan suci baik pura maupun pahatan candi banyak ditemukan pada Daerah Aliran Sungai (DAS) khususnya DAS Pakerisan. Inilah kenyataan yang tidak dapat dipungkiri bahwa peradaban zaman Bali Kuno tidak dapat dipisahkan dengan air. Manfaat penelitian ini adalah untuk memberikan gambaran kepada masyarakat bahwa peradaban Bali Kuno tidak dapat dikesampingkan dengan air sebagai sumber kehidupan. Oleh karena itu, air sebagai sumber kehidupan harus tetap dijaga agar selalu memberikan manfaat bagi perjalan hidup manusia.

\section{Metode Penelitian}

Untuk keperluan analisis diperlukan sumber data baik data primer maupun data sekunder. Data primer dikumpulkan dengan menggunakan cara observasi langsung kelapangan terutama situs-situs yang berada disekitar DAS Pakerisan, sementara data sekunder dikumpulkan melalui studi pustaka terutama yang berkaitan dengan pokok permasalahan. Setelah data terkumpul dilanjutkan dengan analisis yang dilakukan dengan analisis kualitatif dan kontekstual, kemudian dilanjutkan dengan interpretasi.

\section{Hasil dan Pembahasan}

Ketika peradaban manusia mengalami perkembangan dan dengan hadirnya peradaban Hindu Budha ke Indonesia sejak abad ke-5 M, tidak dapat dikesampingkan dari kehidupan laut atau sungai. Sebut misalnya Kerajaan Tarumanegara yang dibangun oleh Raja Purnawarmanabad ke-5. Dari Prasasti Tugu yang ditemukan di daerah Cilincing Jakarta mengindikasikan bahwa Kerajaan Tarumanegara terletak di bentaran kali atau sungai (Kalai Ciliwung) yang setiap musim hujan menimbulkan bencana banjir. Karena kehawatiran raja terhadap bahaya banjir ini, lalu raja memerintahkan untuk menggali sungai Gomati untuk mengalirkan airnya agar kerajaan terhindar dari banjir (Soemadio ed, 2008: 40). Selanjutnya adalah Kerajaan Sriwijaya yang oleh para ahli diduga lokasinya di Palembang, yaitu ditepi sungai Batanghari (Coedes, 1999; Soemadio ed, 2008: 56). Sriwijaya sebagai kerajaan yang menguasai perairan untuk melakukan kegiatan perdagangan sehingga mampu meningkatkan ekonomi kerajaan dari 
pajak-pajak yang diperoleh melalui aktivitas perdagangan dengan berbagai bangsa di dunia. Itulah sebabnya, kerajaan ini oleh para arkeolog disebut sebagai kerajaan yang bercorak maritim.

Berbeda halnya dengan kerajaan Mataran Kuno yang berkembang abad ke-8-10 M di Jawa Tengah, walaupun kehidupan masyarakat dan pemerintahannya bergantung dari kehidupan agraris, namun dari berbagai bukti baik prasasti maupun relief pada candi menunjukan kehidupan bercocok tanam padi sawah. Ini menjadi bukti bahwa masyarakat Mataram Kuno sangat tergantung pada air untuk memenuhi aktivitas bercocok tanam mereka. Demikian pula halnya setelah pusat kekuasaan Mataram pindah ke Medang di Jawa Timur, bahkan ketika Majapahit muncul sebagai kekuatan baru setelah runtuhnya Singosari berusaha mengembangkan sungai Brantas yang membelah kota Surabaya menjadi urat nadi jalur pelayaran dengan masyarakat luar. Upaya membangun bendungan yang dilakukan oleh para penguasa mengindikasikan begitu pentingnya sungai Brantas bagi kehidupan masyarakat terutama sekali untuk memenuhi kebutuhan air baik air baku maupun pertanian (Soemadio ed, 2008: 156).

Kerajaan Majapahit sebagai kerajaan bercorak hindu terakhir oleh para ahli dikatakan sebagai kerajaan yang semi maritim. Sebagai kerajaan besar pada masanya, Majapahit dengan armada laut serta keperkasaan mahapatih Gajah Mada mampu menyatukan wilayahwilayah yang ada di Nusantara bahkan menurut catatan Negarakrtagama beberapa wilayah yang ada di luar Indonesia pun menjadi bagian dari kerajaan Majapahit seperti Singapura, Malaysia, Brunei, Papua Nugini, Thailand, Filipina (Slametmuljana, 1979: 170). Untuk melancarkan ekspansinya ke berbagai wilayah ini, Gajah Mada tentu memanfaatkan kekuatan armada laut yang dimiliki oleh Kerajaan Majapahit. Dengan armada yang tangguh ini mampu mengarungi lautan lepas ke berbagai tujuan yang diinginkan. Dengan upaya yang gigih dan kerja keras Gajah Mada, akhirnya berhasil menyatukan kerajaankerajaan kecil di bawah panji-panji Majapahit. Sungai Brantas saat itu menjadi urat nadi untuk kegiatan pelayaran baik perdagangan maupun kepentingan armada lautnya (Slametmuljana, 1979: 177).

Bagaimana halnya dengan kerajaan Bali Kuno, apakah juga peradabannya dibangun didekat sungai? Secara empiris bukti-bukti arkeologis membuktikan bahwa situs-situs bangunan suci dari masa Bali Kuno didirikan diantara DAS Pakerisan dan Petanu. Pada kedua DAS inilah banyak ditemukan situs bangunan candi maupun bangunan suci pura, mulai dari utara ke selatan dan berakhir dengan adanya pahatan Candi Tebing Tegalinggah. Semakin keselatan jumlah situs pun mulai berkurang karena wilayah datarannya sudah mendekati pantai. Banyaknya situs-situs arkeologi yang terdapat di wilayah DAS ini, mengindikasikan bahwa daerah ini dimasa lalu kemungkinan merupakan pusat pemerintahan dari kerajaan Bali Kuno. DAS Pakerisan yang membentang dari utara ke selatan dan bermuara di pantai Lebih, mendapatkan pasokan air dari beberapa sumber mata air yang muncul di beberapa tempat tebing sungai ini seperti mata air Selukat di hulu, kemudian mata air yang cukup besar Tirta Empul, serta mata air Yeh Mangening. Kedua mata air yang disebutkan terakhir menjadi sumber air baku maupun sumber air irigasi bagi pertanian yang ada di selatannya. Selain sebagai sumber air baku dan irigasi, mata air ini juga diyakini sebagai air suci yang diperlukan oleh umat Hindu untuk aktivitas keaagamaan.

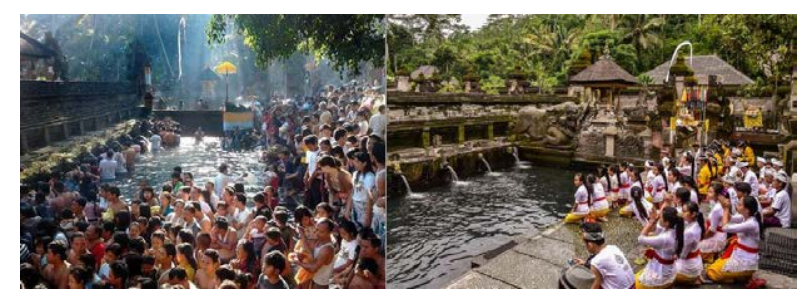

Aktivitas melukat di pura tirtha empul (Sumber: Google, 2020)

Sekalipun kita tidak dapat memastikan letak keraton Kerajaan Bali Kuno ada diantara kedua DAS ini, tetapi setidak-tidaknya banyaknya bangunan suci yang ada telah mengindikasikan bahwa di wilayah ini menjadi tempat baik untuk mendirikan bangunan suci keagamaan. Selain sebagai tempat berdirinya bangunan suci keagamaan, wilayah ini diyakini pula menjadi tempat bermukim bagi masyarakat pendukung dari kebudayaan itu sendiri. Hal ini bersesuaian dengan kondisi geografis wilayah ini yang memiliki ketinggian antara 175-775 mt diatas permukaan laut serta kemiringan lahan antara $0 \%$ hingga $15 \%$. Kondisi lahan seperti ini menggambarkan bahwa wilayah ini tergolong 
datar hingga bergelombang ke arah utara. Kondisi lahan seperti itu, menjadikan wilayah ini sebagai lahan pertanian sawah yang cukup baik walaupun dibeberapa tempat harus diusahakan dengan teknik terasering.

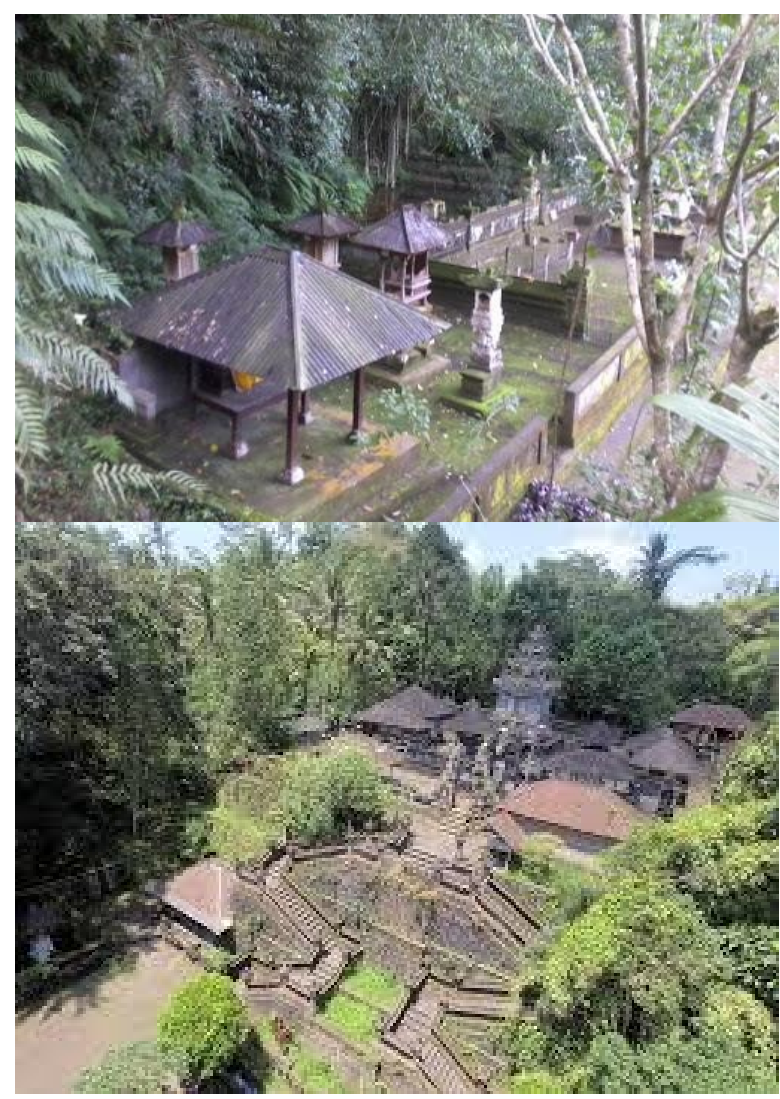

Situs Pura Mangening (Sumber: Google, 2020)

Pemanfaatan lahan sebagai pertanian sawah maupun ladang/huma disebabkan karena tersedianya sumberdaya air yang mencukupi serta kesuburan tanahnya. Berdasarkan Peta Jenis Tanah yang dikeluarkan oleh Badan Pertanahan Nasional Kabupaten Gianyar (1989) disebutkan wilayah Tampaksiring terdiri atas jenis tanah regosol, coklat kelabu, dan regosol kekuning- kuningan. Jenis tanah regosol kelabu terdapat dibagian selatan wilayah ini. Jenis tanah regosol kelabu merupakan jenis tanah yang tergolong masih muda dan belum mengalami pelapukan yang sempurna serta belum menampakan adanya horizon, profilnya bersifat homogin, teksturnya tergolong geluh pasiran (sandy loam), berstruktur granuler hingga berbutir tunggal, konsistensi tanah lepas, warna tanah coklat keabu-abuan hingga kelabu kecoklat-coklatan, dan drainasenya lambat hingga sedang. Sementara tanah regosol coklat kekuning-kuningan dengan ciri-cirinya tekstur geluh lempungan, struktur tanah halus hingga berkerikil warna tanahnya kelabu. Jenis tanah ini terdapat dibagian utara Tampaksiring Kesuburan fisik tanah sedang hingga tinggi, tekstur tanah kasar hingga halus, permeabilitas agak poris dibagian utara sebaliknya dibagian selatan tidak bersifat poris dan daya ikat tanah terhadap air sedang hingga tinggi dibagian selatan (Srijaya, 1996). Jenis tanah semacam ini merupakan lahan pertanian sawah yang baik apabila mendapat pasokan air yang cukup.

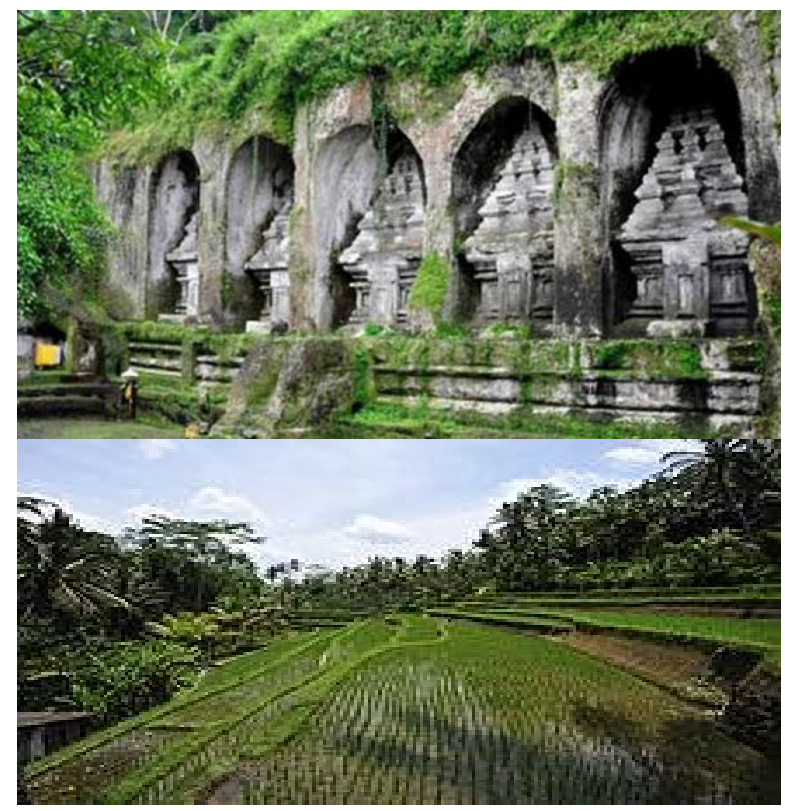

Candi Gunung Kawi Tampaksiring dan hamparan sawah di sisi barat Candi Gunung Kawi

(Sumber: Google, 2020)

Tanah yang subur ini dipengaruhi oleh adanya endapan abu vulkan muda yang dikeluarkan oleh gunung Batur purba. Adanya endapan abu vulkan ini dikuatkan oleh hasil penelitian geologi yang dilakukan PoeboHadiwidjojo (1978: 86-87). Dalam penelitian itu disebutkan bahwa daerah yang tertutup oleh abu vulkanis muda mempunyai kesuburan yang tinggi sebagaimana diperlihatkan oleh lahanlahan yang terdapat dilereng barat dan selatan Gunung Batur. Dikatakan pula bahwa tanah yang bahan induknya abu vulkan muda cenderung memiliki kesuburan yang tinggi, sebaliknya tanah yang tertutup oleh abu vulkan tua cenderung kesuburannya sedang serta tanah yang terbentuk karena batuan sedimen cenderung tidak subur. Kondisi seperti 
digambarkan di atas masih teramati dilapangan, dimana sebagian dari daerah penelitian merupakan lahan pertanian sawah yang subur dan sebagian lagi sebagai lahan tegalan (Srijaya dkk, 2001; Srijaya, 1996: 115). Gambaran di atas mengindikasikan bahwa daerah penelitian mempunyai potensi ekologis yang sangat baik untuk dimanfaatkan sebagai permukiman masyarakat. Dengan adanya permukiman akan disertai pula dengan munculnya sebuah peradaban baik yang berkaitan dengan pertanian maupun aktivitas keagamaan.

Dalam hubungannya dengan kegiatan keagamaan masyarakat yang bermukim diwilayah ini membangun tempat-tempat suci yang menggambarkan kehadiran peradaban Hindu dan Buddha di Bali pada waktu itu. Walaupun yang dominan kita saksikan bangunan suci pura, namun jauh sebelum kehadiran peradaban Hindu dan Buddha ini sudah berkembang kepercayaan terhadap roh suci leluhur yang bersumber pada masa pra Hindu. Itulah sebabnya di banyak bangunan suci pura diketemukan wujud bangunan megalitik ataupun arca yang menggambarkan karakter megalitik. Pendirian bangunan suci sebagaimana digambarkan dalam kitab-kitab India kuno Manasara-Silpasastra dan Silpaprakasa haruslah memenuhi beberapa syarat.

Dalam kitab Manasara-Silpasastra, dijelaskan bahwa sebelum bangunan kuil didirikan, arsitek pendeta (sthapaka) dan arsitek perencana (sthapati) harus terlebih dahulu melakukan penilaian terhadap kondisi dan kemampuan lahan yang akan digunakan sebagai tempat berdirinya bangunan tersebut (Acharya dalam Mundardjito, 2002: 11; Kramrisch, 1946: 3-6). Selain penilaian terhadap lahan, kitab india kuno itu memberikan petunjuk mengenai teknikteknik untuk mengkaji lahan calon bangunan kuil, antara lain dengan cara mengisi lubang uji dengan air untuk mengetahui daya serap tanahnya, menimbun tanah ke dalam lubang galianuntuk dinilai derajat kemelesakannya, dan menebar bibit tanaman dipermukaan lahan yang sudah dibajak untuk dinilai tingkat kesuburan tanahnya.

Selain itu, dalam kitab ManasaraSilpasastra juga dijelaskan bahwa letak bangunan kuil harus berdekatan dengan air, karena air mempunyai potensi untuk membersihkan, menyucikan, dan menyuburkan. Bahkan dalam kitab India kuno lainnya yaitu
Silpaprakasa ditegaskan bahwa suatu bidanglahan tanpa sungai harus dihindari sebagai tempat berdirinya kuil (Boner dan Sarma, 1966: 10). Karenanya menjadi syarat, demikian Soekmono, bahwa pembangunan sebuah kuil sebagai pertanda kesucian suatu tempat dan juga sebagai pusat dan sasaran pemujaan, harus berdekatan dengan sungai (tirtha) (Soekmono, 1977: 238).

Dengan keterangan yang dicontohkan Manasara-Silpasastra dan Silpaprakasa dapat disimpulkan bahwa pertimbangan potensi lahan dan air, ikut memegang peranan penting dalam proses pengambilan keputusan yang dilakukan oleh para arsitek masa lalu berkenaan dengan lokasi yang akan digunakan sebagai tempat berdirinya setiap bangunan yang bersifat keagamaan. Pentingnya kemampuan lahan yang akan digunakan sebagai lokasi bangunan keagamaan, kiranya dapat dipertegas dengan pernyataan Soekmono sebagai berikut.

"Sesuatu tempat suci adalah suci karena potensinya sendiri. Maka sesungguhnya, yang primer adalah tanahnya, sedang kuilnya hanya menduduki tempat nomor dua" (Soekomono, 1977: 238).

Apa yang disajikan dalam kitab India kuno Manasara - Sastra dan Sipaprakasa, secara empiris bersesuaian dengan persebaran situs-situs yang ada di wilayah penelitian dari hulu ke hilir populasinya cukup padat. Padatnya situs-situs bangunan suci ini mengindikasikan banyaknya masayarakat yang bermukim di wilayah penelitian sehingga mereka mampu mendirikan banyak tempat-tempat suci pura maupun pahatan candi tebing. Hampir semua situs bangunan suci berdekatan dengan dua sungai, yaitu Tukad Pakerisan dan Petanu serta dilihat dari potensi lahannya sebagaimana digambarkan dari hasil pemetaan yang dilakukan oleh Badan Pertanahan Nasional Kabupaten Gianyar memperlihatkan bahwa lahan di wilayah penelitian merupakan lahan yang subur.

Oleh karena itu, dalam upaya memahami perilaku masyarakat masa lalu terutama dalam kaitannya dengan aktivitas permukiman maka diperlukan sebuah pendekatan. Pendekatan yang sesuai dengan tujuan penelitian ini adalah ecological determinants approach (Thomas dalam Mundardjito, 2002: 15). Pendekatan ini tidak menganggap bahwa suatu lingkungan fisik menentukan seluruh aspek kebudayaan, tetapi memandang bahwa sekumpulan faktor 
lingkungan yang khas dalam suatu daerah mengkondisikan penempatan situs-situs arkeologi. Pendekatan determinan ekologi ini memandang secara sederhana bahwa pemukinan manusia masa lalu acapkali ditempatkan pada suatu bentang lahan tertentu sebagai jawaban terhadap seperangkat faktor lingkungan khas yang berperan dalam menentukan penempatannya. Hal ini tidak berarti faktor lingkungan merupakan satu-satunya faktor yang mempengaruhi keletakan suatu situs arkeologi. Tetapi dengan menggunakan pendekatan determinan ekologi maka pola persebaran situs dapat dikaitkan dengan pola pemanfaat sumberdaya alam dimasa lalu dan pola seperti ini mungkin dimaksudkan sebagai upaya minimalisasi energi dan memaksimalkan hasil kerja (Clarke dalam Mundardjito, 2002).

DAS Pakerisan dan Petanu merupakan suatu kawasan yang mempunyai nilai budaya yang sangat tinggi. Kawasan yang memanjang dari utara ke selatan Kabupaten Gianyar mempunyai sumberdaya alam yang potensial dipilih menjadi hunian dan komunitas. Deretan persawahan yang subur dengan aliran resapan Gunung Batur, Yeh Mangening, serta Tirta Empulmenjadikan kawasan ini sebagai kawasan yang memiliki sumberdaya alam yang memberikan harapan bagi kehidupan. Adanya dukungan sumberdaya alam ini membuat komunitas yang ada berusaha memenuhi kebutuhan spiritualnya (keagamaan) dengan memanfaatkan lingkungan disekitarnya tanpa menimbulkan kerusakan. Sebagai kawasan suci, disepanjang DAS Pakerisan dan Petanu banyak terdapat situs-situs bangunan suci pura atau pahatan candi tebing (Mitha Mahastuti, 2018: $35)$.

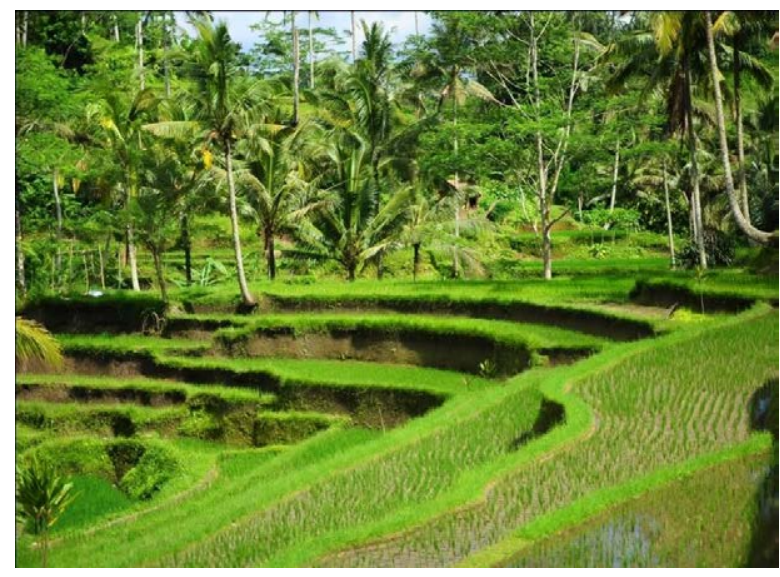

Pengolahan lahan dengan cara terasering
Sumberdaya alam khususnya tersedianya air yang permanen dari Tukad Pakerisan, memberikan manfaat bagi warga yang bermukim disekitar kawasan ini. Mata air yang keluar di Tirta Empul menjadi sumber air baku bagi masyarakat yang ada disekitarnya dengan menggunakan teknologi untuk mengangkat ke atas sehingga dapat dinikmati oleh masayarakat. Sementara itu, untuk memenuhi kebutuhan air irigasi yang besar, dari mata air ini dialirkan ke Subak Pulagan yang telah ditetapkan sebagai warisan dunia oleh UNESCO tahun 2012. Subak Pulagan sepenuhnya mendapat pasokan air dari sumber mata air Tirtha Empul yang dialirkan melalui jaringan irigasi yang dikelola oleh krama Subak. Di samping kedua manfaat di atas, air yang keluar dari Tirta Empul ini juga dimanfaatkan untuk berbagai keperluan air suci yang diperlukan oleh masyarakat yang beragama hindu seperti tirta. Yang menarik dari sumber mata air ini adalah adanya keyakinan masyarakat untuk membersihkan diri dari berbagai kekotoran yaitu dengan cara melukat (mandi) pada sebuah kolam yang disediakan di Jeroan pura ini. Sumber air Tirta Empul sudah sejak dahulu dimanfaatkan untuk kepentingan ritual keagamaan tetapi juga dimanfaatkan sebagai pemandian dan memenuhuhi kebutuhan akan air irigasi. Pemanfaatan air ini memang sangat penting karena air merupakan sumber kehidupan utama yang terdapat di bumi. Pengaturan terhadap keperluan air sudah dilakukan oleh masyarakat Bali sejak dahulu dimana setiap pemanfaatannya diusahakan agar selalalu memperhatikan kelestarian dan kebersihan air tersebut. Itulah yang melatari pendirian candi tebing ditepi Tukad Pakerisan, dimana fungsi candi pada lanskap ini tidak semata-mata sebagai tempat pemujaan tetapi juga merupakan bagian dari kearifan lokal masyarakat pada masa lampau dalam menyikapi kesucian sungai dan kelestarian DAS (Anonim, t.t; Geria, 2006: 4).

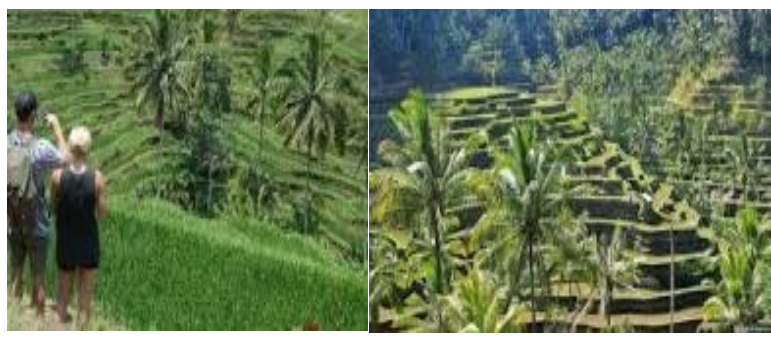

Subak pulagan sebagai warisan dunia 
Banyaknya warisan budaya yang berupa situs bangunan suci pura beserta tinggalan yang ada di dalamnya merupakan bentuk nyata kepercayaan masyarakat Bali pada masa lalu yang menganut agama Hindu atau yang sering pula disebut sebagai Agama Tirta dimana air menjadi bagian yang sangat penting dalam setiap kegiatan ritual keagamaan, maka tidak mengherankan apabila bangunan-bangunan suci pada masa Bali Kuno letaknya berdekatan dengan sumber air maupun memiliki petirtaan (Anonim, tt: 1).

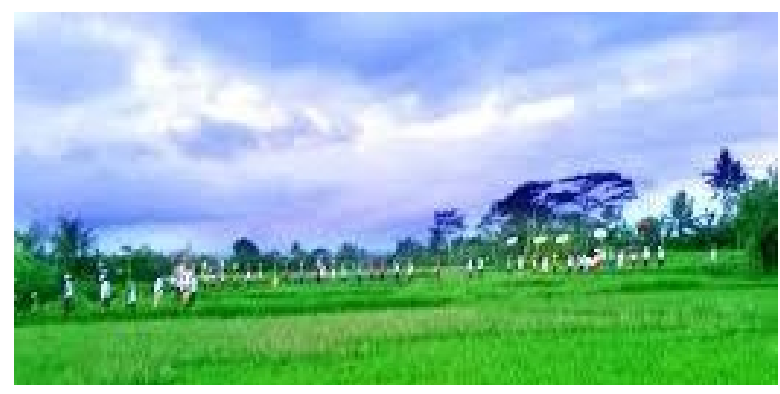

Hamparan sawah Kulub

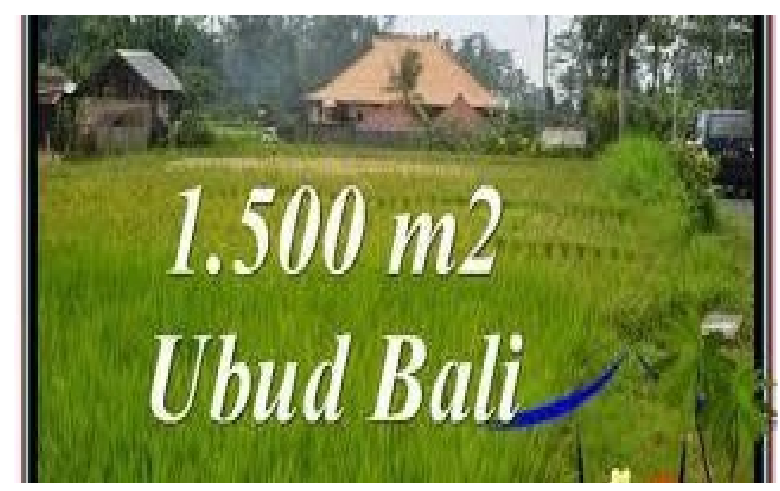

Ancaman bagi kelestarian subak

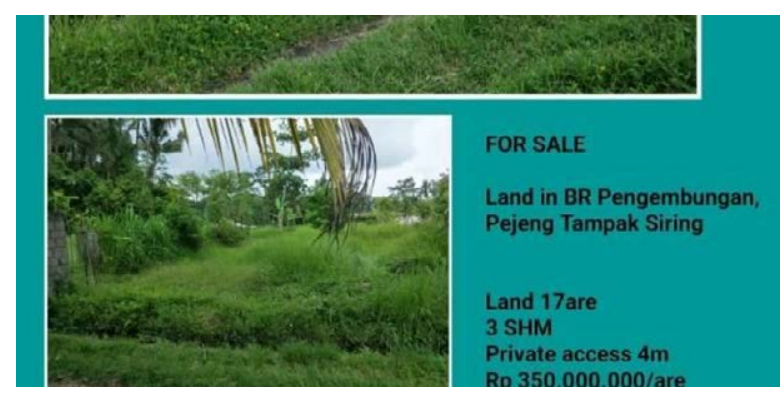

Sawah di tengah ancaman pembangunan

Demikian juga dengan mata air yang terdapat di Pura Mangening yang lokasinya tidak jauh dari pura Tirta Empul. Sumber air yang terdapat di barat pura Mangening terletak pada sebuah lembah yang keluar di bawah sebuah pohon beringin. Mata air ini dimanfaatkan untuk keperluan spiritual (keagamaan) dan memenuhi kebutuhan air irigasi. Sebagai air suci, air yang keluar dari mata air ini kemudian dialirkan ke dalam sebelas pancuran yang ada di sisi barat sebagai tirta. Air yang mengalir ke pancuran ini kemudian ditampung di dalam kolam yang ada di depannya dan air dari kolam ini kemudian dialirkan ke Tukad Pakerisan (Anonim, t.t: 5). Sebagai sumberdaya alam yang memiliki volume cukup besar, maka pemanfaatannya tidak saja untuk kepentingan ritual kegamaan tetapi juga untuk keperluan mengairi sawah yang ada di Subak Kulub Atas dan Kulub Bawah di wilayah Kecamatan Tampaksiring. Sebagai bentuk kepercayaan masyarakat terutama krama subak terhadap sumber mata air ini maka dibuatlah sebuah palinggih subak yang berada di dekat mata air ini (Srijaya dan Tarawiguna, 2018: 24).

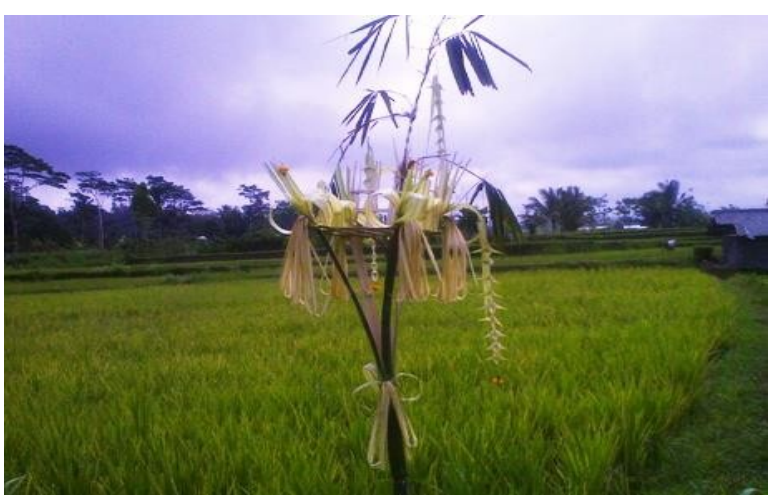

Upacara Biukukung

Sebagai bentuk keterkaitan antara subak sebagai organisasi pengelolaan air oleh masyarakat di Bali umumnya dan di wilayah Tampaksiring khususnya, kemudian dibangun sebuah bangunan/pelinggih untuk memuliakan Tuhan dalam manifestasinya sebagai dewa yang memberikan kemakmuran dan kesuburan bagi masayarakat, yaitu di pura Tirta Empul untuk warga Subak Pulagan dan di Pura Mangening untuk Subak Kulub. Melalui bangunan suci inilah kedua warga subak melakukan kegiatan keagamaan yang terkait dengan aktivitas pertanian.

\section{Simpulan}

Berdasarkan uraian singkat di atas, dapat disimpulkan beberapa hal sebagai berikut. 
1. Air merupakan kebutuhan dasar mahluk hidup termasuk manusia. Tanpa air mahluk hidup tidak akan mampu mempertahankan keberlangsungannya.

2. Air sebagai sumberdaya alam memberikan manfaat bagi keberlangsungan pertanian terutama untuk mengairi lahan persawahan yang dikelola dalam bentuk subak.

3. Air menjadi urat nadi pelayaran pada masa lalu terutama sungai-sungai yang besar,sehingga tranportsi air menjadi satusatunya alat untuk menghubungkan satu tempatdengan tempat lainnya.

4. Air dalam konteks keagamaan, merupakan air suci yang dapat menghilangkan klesa (kotoran) pada diri manusia, disamping difungsikan sebagai air suci.

5. Air di masa lalu menjadi tempat munculnya peradaban manusia sejak ribuan tahunsebelum masehi.

\section{Daftar Pustaka}

Acharya, Prasanna Kumar, 1933 Arsitecture of Manasara. London: Oxford University Press. Anonim, t.t. DAS Pakerisan Refleksi Warisan Budaya Dunia.

Boner, Alice dan Sadasiva Rath Sarma, 1966. Silpaprakasa. Leide: E. J. Brill.

Coedes, George, 1999. Kedatuan Sriwijaya. Jakarta: Pusat Penelitian Arkeologi Nasional dan EFEO.

Mitha Mahastuti, Ni Nyoman. 2018. Kontektual Warisan Budaya Dunia DAS Pakerisan Terhadap Kesinambungan Budaya Bali. Program Studi Arsitektur Fakultas Teknik Universitas Udayana.

Mundardjito. 2002. Pertimbangan Ekologis Penempatan Situs Masa Hindu Budha di Daerah Yogyakarta. Jakarta: Wedatama Widya Sastra-EFEO.
Noeljani, R. 1992. Geografi Sejarah Dunia. Bandung: Bina Ilmu.

Soejono, R.P, ed. 2000. "Jaman Prasejarah". Dalam Noegroho Notosusanto dan Djoened Poespowardojo Sejarah Nasional Indonesia I. Jakarta: Balai Pustaka.

Soemadio, Bambang ed. 2008 "Jaman Kuno". Dalam Noegroho Notosusanto dan Djoened Poespowardojo Sejarah Nasional Indonesia II. Jakarta: Balai Pustaka.

Slametmuljana. 1979. Negarakertagama dan Tafsir Sejarahnya. Jakarta: Bratara. Slametmuljana. 1981. Kuntala, Sriwijaya dan Swarnabhumi. Jakarta: Idayu Press.

Srijaya, I Wayan. 1996. "Pola Persebaran Situs Masa Hindu-Buda di Kabupaten Gianyar: Kajian Ekologi”. Tesis. Jakarta: Fakultas Pascasarjana Universitas Indonesia.

Srijaya, I Wayan dan I Gusti Ngurah Tara Wiguna. 2018. "Warisan Budaya Dunia DAS Pakerisan dan Petanu sebagai Destinasi Wisata di Kabupaten Gianyar" Dalam Jurnal Stupika (Juournal of Archaeology and Culture) Volume 2, Nomor 1, Oktober 2018 ISSN 2528-4509 Hal. 20-31. Denpasar: Program Studi Arkeologi Universitas Udayana.

\section{Sumber Internet}

http://fwatcher.fwi.or.id/merawat-air-dengankearifan-lokal-di-bali/ Diunduh Tanggal 29 agustus2020 Pukul 21.00 Wita.

http://Javanesesaiivism.com/wp.content/ uploads/2017/07/Air dalam Kebudayaan Bali pdf/Diunduh Tanggal 29 Agustus 2020 Pukul 21.00 Wita. 